\title{
Remembrance as an optical mind-lens in the editing of memories by means of participatory listening in liturgy
}

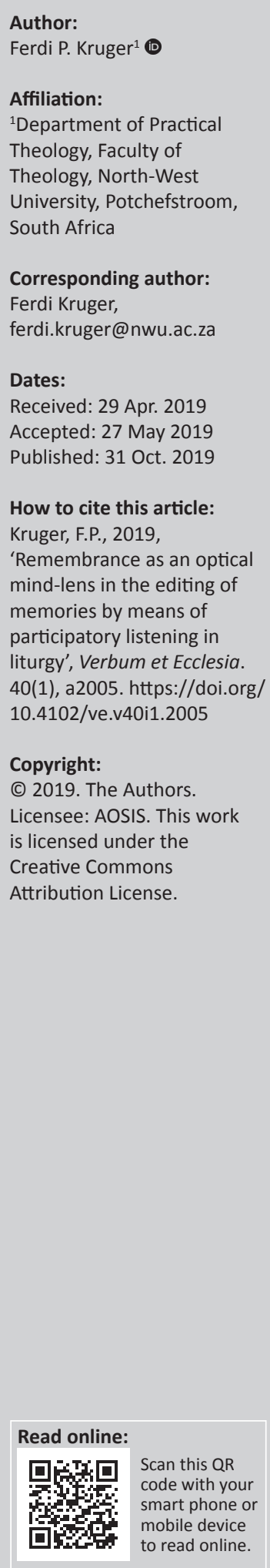

Research indicates that worshippers have to contend with a process of remembrance (recognition) when they participate in liturgy. This article identifies two focal points within the listening process, namely listening as a predominant activity during participation as well as listening that leads to changes in perception, which, in turn, lead to a difference in actions. The research question is: What kind of dynamic perspectives emanate from research on remembrance as a process that edits memories to enable listeners to cultivate a cognisance of seeing? A listener's remembrance has to do with recollecting familiar things, events and words. Remembering brings new meaning and understanding. Recognition is the spark that ignites participants' ability to take part in the listening process. This investigation was conducted on the basis of a practical-theological vantage point and interdisciplinary engagement with social psychology and communication sciences. Anamnesis was examined from the perspective of recognition as viewed in terms of the sermon to the Hebrews. The article closes with perspectives on the creative functioning of recognition as a part of active listening.

Intradisciplinary and/or interdisciplinary implications: This research has an inter-disciplinary focus. The concept of recognition (remembrance) is scrutinised in utilising perspectives from the viewpoint of social psychology as well as communication sciences in order to indicate why active listening is pivotal during the act of listening to sermons.

Keywords: remembrance; recognition; homiletics; liturgics; memories.

\section{Introduction}

Togetherness in society is challenging because people do not see things in the exact same manner and they perceive the reality of history as well as of the challenges in society in diverse ways (Smit 2008:260). Bonhoeffer (1959:8) in particular was concerned about the way in which faith communities perceive reality and raised the challenge of seeing the world sub specie Christi as the paramount theological activity for Christians. Troeger (2009:64) provides a perspective that could assist this process of perceiving when holding that the level of imagination informs engagement with daily life. Imagination, as the word implies, refers to a set of optics held before the mind's eye, as an image of something that is present, but also not present. People could, however, experience liturgy within worship services as mere observers rather than seeing liturgical actions as dynamic, working powers that operate within and through participants towards a responsible way of life.

Smit (2008:262) therefore makes an interesting comment in this regard with the expression of agere sequitur esse [what we do follow from what we are] that should be altered to read agere sequitur videre [what we do follow from what we see]. Hence, active listening within worship is providing the opportunity for becoming silent in order for the memory (remembrance) of the Saviour to flourish (Hauerwas 2002:149; Smith 2013:19). An attentive eye for the remembrance of God's presence in all spheres of human life is vital within this engagement (De Klerk \& Kruger 2017:4). Now, one should concomitantly ask how this aspect could be cultivated in a pervasive way without allowing a praxis of the act of listening to function merely as a unilateral formality.

Here, it is as though two powerful tension (voltage) fields influence each other, namely listening as a single element among others in participating in liturgy and the realisation of the relevance of liturgy for daily life. These focal points are interdependent and are connected to the vividness of remembrance. Within the dynamic flow of actions between these points, the idea of the church as ecclesia audiens (i.e. a listening church), as Karl Barth once described it, should be regarded as important. According to Barth's view, a community of believers is called upon to proclaim 
God's Word but fails in achieving this responsibility when they fail to listen (Ott \& Strauss 2010:266). This is why scholars sometimes refer to the lost skill of listening. The emphasis on listening as one of the activities that aids in a difference in the quality of actions therefore centres on a deep need for an ontological shift towards listening because this results in seeing life through a different lens, resulting in faithful living.

Remembrance is indispensable in unlocking the act of seeing because people use their senses to forge connections with the physical environment to orient themselves in space. An example of this is a view of the past that is not dead and, indeed, not even past. This view expresses the role that the past will inevitably play in present reality. Therefore, the past is not simply the past tense. It is actively present in people's memories and in their imagination. The past could live in either a positive or a negative way in people's thoughts. Exactly how people remember or forget the past, or how they should remember and forget it, is of course a complex matter because of various complex processes of schemes, perception and the functioning of attitudes (Vosloo 2015:3).

This article aims to achieve the following outcomes: firstly, to delineate the interdisciplinary scope of the particular research focus and, secondly, to pen down the relevance of this focus for the disciplines of homiletics and liturgics. One should debate whether the increasing emphasis on participation and experience in liturgy perhaps inadvertently supposes that the listening process is passive. After all, listening should not be understood in abstraction, away from the dialogical interaction of liturgy itself. As the activity of listening is an integral part of liturgy, it plays a paramount role in moving communities of faith in the direction that God has in mind for them as his people within a given context (Cilliers 2001:343). This is why Atkins (2004:25) could state that 'At the heart of all worship, is the act of remembrance'. The research problem for the present research could therefore be formulated in the following manner: What kind of dynamic perspectives could emanate from research on remembrance as a process that edits memories towards enabling listeners to cultivate a cognizance of seeing? ${ }^{1}$

In accordance with Dingemans' (1996b) methodological insight, this research will be organised according to a qualitative literature study, and in this process, acknowledgement is given to existing knowledge within this field (cf. Bothma et al. 2010). This literature will be organised and critically interpreted in the light of the research problem. This article will further be divided into three movements that relate to each other in a hermeneutical manner, namely:

- analysis of the practical theological situation

- normative perspectives

1.During the interpreting stage of listening, we combine the visual and auditory information we receive and try to make meaning out of that information using schemata.
- strategies for changing the problematic praxis not seeing listening as a participatory act.

\section{Remembrance as an optic lens that allows determining the depth level of the sursum corda}

There has been continuous research interest in how modern Christianity could possibly connect with postmodern views that sometimes express dissatisfaction with the traditional way of conducting worship services (cf. Bohannon 2006:56; Brienen 1987:172; Kimball 2004:89-90; McLaren 2008:143; Pakpahan 2012:118; Viola 2008:15; Wepener 2017:136; Wolterstorff 1992:276). In a similar vein, research highlights profound concerns about the praxis of worship services that, viewed from a historical perspective, gradually turned into little more than preaching services with a one-sided emphasis on listening (cf. De Klerk \& Kruger 2017:33; Wolterstorff 1992:292). Little wonder, therefore, that creative engagement of listeners or the idea of providing an interpretative space within the listening process where listeners should complete the sermon within the reality of their own lives has become a specific focal point in research (Allen 2010:8-9; Buttrick 1987:70; Malström 2016: 572; McClure 1995:22).

Reflection on this topic has to deal with the idea that liturgy itself consists of an ensemble of signs or actions where the dominant value lies in the order of signification of meaning (Kubicki 2006:63). Viewed from a terminological perspective, worship services are focussed on the significance of meeting the living God. At the heart of this idea is the consolation that God intercedes in the congregation so that it might rise to him (Immink 2014:163; Pleizier 2013:233). The first movement in this dynamic sweep is always God's move towards the congregation, and the first decisive movement of worship is mirrored by the upward movement of God's people, called the sursum corda or the lifting of our hearts (Witvliet 2003:135). The idea of remembering what the worship service is about and also of elevating a meeting from a mere cognisance of just another kind of meeting is therefore clear. The power of anamnesis therefore lies in reliving the saving acts of God in such a powerful manner that it enables us to appropriate all God's promises. It is about the realisation that liturgy also gives new meaning to the hourglass of time.

Viewed from a liturgical angle, remembrance entails the memory of familiar aspects that form the foundation for living memories and vivid experiences (Welker 2000:126). Remembrance therefore draws people into the reality of the fullness of life in Christ. In much-discussed words, Moltmann (2008) indicates precisely this importance of remembrance:

$[W]$ ithout the memory of Christ's passion there is no Christian meditation on the future life and conversely, without hope for the coming of Christ and therefore the remembrance of Christ loses its power. (p. 103)

It is in itself something that, in today's popular parlance, could be said to blow one's mind. But one should acknowledge 
that this does not involve a movement back in time through mere memories (in memoriam) but rather that it involves a vivid (dynamic) movement of remembrance of the reality of God's presence. People normally remember pieces of an event but tend to forget others, and the event details being recalled are shaped by their current mindset and moulded by thoughts and experiences that have occurred between the original event and the moment of remembering (Kensinger 2009). People do not actually listen with their ears only. They hear with their eyes (vivid remembrances) and with their sense of touch as they become aware of the feelings and emotions that arise from a particular message.

For people to meaningfully participate in liturgy through active listening and to see through remembering, the lens of sursum corda in liturgy means that the whole human being has to be engaged in the listening process and to be renewed through the senses. An understanding of the sursum corda that is only assigned to the celebration of sacraments should be avoided. Recognition of the fact that liturgy actually signifies something beyond immediate experience indemnifies liturgy from mere formality (Saliers 1994:144). In liturgy, people do not only hear in order to hear or sing in order to make music, and they do not only speak to teach and learn. Hauerwas (1989:95) is well-known for the expression that worship actually amounts to enabling participants to look in the right direction of meaningfulness for daily life. In this regard, Smit (2008:262) refers to Calvin's view, namely that humans are spiritually spoken blind and can't see. Therefore, God is speaking to people and, based on people hearing God's voice, they can now see. In addition, Wolterstorff (1992:292) explains that liturgy is a specific manifestation of a vision regarding what God and his children have to do with each other. Green (1989:107) explains that in listening with the aim of actually hearing, people inevitably learn to see the relevance of what they are listening to. Liturgy in itself is parabolic, which takes people to a different space (as per the sursum corda), and liturgy speaks of something poignant that tries to make connections between realities (Saliers 1994:144).

This kind of connectivity enables Hervieu-Léger (2000:87) as a representative exponent among scholars at the turn of a new millennium who have shown interest in a consumer culture as well as a crisis of memory (amnesia) in a postmodern world - to reflect on the significance of remembrance. The idea of novum in vetere latet [the new is hidden in the old] is therefore prominent within her research. Hervieu-Léger underlines the idea that, after all, religion and memory are intrinsically bound together. For instance, a religious community accepts tradition (inter alia within the accepted confession and liturgical activities) and draws from it the necessary continuity between the past and the present (Urbaniak 2015:1). The German concept of Wiedererinnerung explains this exact idea and denotes the idea of remembering things again, in effect re-remembering something. The idea of reminding what has been dismembered or amputated is therefore evident. Within a liturgical context, we can further speak about co-remembering because of the interaction within a community of believers while worshipping.
Liturgy could enable participants to remind each other to co-remember while they are actively listening.

The literary postmodern scholar Ricoeur (2004:128) elaborates intriguingly on this idea and states that a creative dialectical tension between individual and collective memory will always exist, representing a kind of tension that cannot be completely resolved. ${ }^{2}$ People usually remember pieces of an event (liturgy and preaching) but tend to forget others, and those event details that are recalled are shaped by their current mindset and moulded by thoughts and experiences that have occurred between the original event and the moment of remembering (Kensinger 2009:8). To put it concretely, experiences that elicit emotional arousals are more likely to be remembered than experiences that do not evoke an emotional response. A worrisome aspect in this regard is that negative information will be remembered with a greater sense of vividness than positive information (Dewhurst \& Perry 2000:545). People often claim that they remember the details of negative events, whereas they are more likely to know only from a distance that a positive event occurred, without remembering the particular details of the latter (Ochsner 2000:244). In other words, memories are in need of editing, and this is exactly why the research field of remembrance should be seen as influential. The activity of listening while participating in liturgy, which takes place on a regular basis, offers important glimpses of the potential to stir someone's memory (Arthurs 2017:5-6).

Listeners are in need of the stirring of memories while remembering or even partially concealing past experiences. In fact, in every worship service, participants in liturgy remember the good message regarding Christ's death and his resurrection (Saliers 2010:8; Smit 2008:310). All people have memories of their relationship with God, of previous sermons about the same passage and the image of reality created by messages they have been exposed to. It is important to note that people are incapable of paying attention to all data they receive. This could also explain why people are listening to the same message about Christ's death and resurrection but different aspects thereof are being remembered. People are after all harmonising and are inventing detail to make a memory harmonious with their current beliefs. Schlinger (2014:11) therefore takes the idea of sursum corda one step further and indicates that listeners eventually act dialogically as speakers themselves when they submit to listening to sermons (scholars are also referring to the idea of an exchange of ownership of sermons), react to sermons and respond to sermons in daily life. The act of listening to words retrieves vivid images from people's memories.

This will now be elucidated according to two prominent moves of listening within liturgy, namely singing and the Word service. England (2017:18) elaborates on vivid images

2. Ricoeur (2004:131) is therefore helping us to realise that an intermediate level of refer (2004:131) is therefor refis 'privien privileged others in defining the close relationships between people that are influential in the remembrance of memories. In remembering, communion with other participants contributes in a profound manner to meaningfulness. 
and mentions the spatial promise of listening amid others to participants singing as well as the functioning of listening to liturgical music. This is all the more true because, within liturgy, music and singing are purposefully designed to communicate. Listening to words and to the way in which people express themselves provide cultivating elements towards recognising significance. England (2017:17) continues in this vein, indicating that sacred music continues to be a means of negotiating the relationship between humanselves and the sacred. The author (England 2017) concurs with and highlights the following:

Pitched sounds must succeed one another in time, in order to constitute any sense of melodic continuity. As they pass one's hearing of them, so they fade and then die into the past, but the one who is listening to them holds those pasts present to and in the sounds that follow them. In this way, to transpose the grammar, the listener creates a form of narrative continuity. (p. 21)

Gaarden (2014a) applies the same principle to the act of listening to the Word service that includes Scripture reading and preaching. The main aim of listening is not a mental understanding of words, but rather a new understanding (meaning-identification by participants as meaning seekers) where, for example, listeners' own stories enter into dialogue with the words. The words utilised unveil and activate a remembrance of experiences. One word, even one concept, could unveil many things. Delivering messages to listeners should not only be constructed correctly according to certain homiletical principles but should above all allow listeners to see God according to remembrances.

Long (2009a:162) explains the difficult task of enabling the act of listening within liturgy to translate a theological claim into everyday experience and to help people see what this could possibly look like in their own lives. It is an illusion to think that what is heard by the listeners will necessarily bear resemblance to what preachers have said, and this should rather be avoided. Based on the footprint of this recognition, Cilliers (2012:5-6) thoroughly indicates that listening can play an important role in adding colourful perspectives within the mind's eye. This art of the re-visioning of reality could also be called the reframing of perspective according to Cilliers. Reframing is about revisiting existing things of the old and the past. It is articulated in the prefix 're'. The prefix 're' has the connotation of again and again. It is both re and creation at the same time (Cilliers 2012:6). Within this unique functioning of reframing, the unique place of remembrance should be taken into account. Let us look into this matter, setting out with an analysis of the practical theological situation.

\section{Analysis of the practical theological situation \\ Descriptive perspectives and charting the homiletical landscape}

Changing trends demarcate directional contours of a distance that practical theologians have travelled over the years. Some scholars even mention the idea of a paradigm shift within practical theology (cf. Louw 2011:13). Louw highlights a paradigm shift that has occurred over the years, namely a movement from ecclesiastical to practical theology, a shift that should engage in critical dialogue with the zeitgeist in order to transform society. This shift further gravitates towards discernment of ethical norms for individual transformation and results in the making of theory by means of critical engagement with practice. A further paradigm shift occurred when greater emphasis was placed on social sciences, which in its turn also culminates in a shift that focuses on praxis (doing) (Dingemans 1996).

The important contribution of Fred Craddock in prompting preachers towards an inductive approach towards sermons moreover announced a new dawn in an increasing liturgical awareness. The idea that preaching should lure listeners to a long journey of surprise in order to exclaim 'Aha, I get it' is of direct interest in this respect (Craddock 1985:21). The German scholar Ernst Lange concurs with Craddock and developed a new theory for homiletics, declaring that the listener is the theme of the sermon (Lange 1987:59). Lange was outspoken about the fact that the situation of the listener should also be an integral point of departure in the preparation and delivery of a sermon. Scholars in favour of a new homiletic paradigm have rapidly been reflecting on what preaching should actually achieve. A few examples of influential scholars that soon raised their voices in favour of a new homiletic paradigm are Buttrick (1987), whose work centres on moves and structures within a sermon, 1987, who focusses on the homiletical plot. This kind of research opened the door for further intriguing research on permeating communication with an emphasis on context (including the liturgical context). The echoes of these voices were also influential in the recognition that people become what they worship (Beale 2008:21).

Different variations on the theme of preaching within the context of liturgy that would communicate with listeners within the concreteness of their own lives were soon offered on aspects such as the accent on communicative preaching (Dingemans 1996:44; Pieterse 2001:68), creative preaching (Cilliers 2001:130), prophetic preaching (Brueggemann 1978:13; Müller 1996:65; Pieterse 2001:95; Tubbs-Tisdale 2010:61) and the ethical dimension in preaching (Cilliers 2000:20; De Wet \& Kruger 2013:19; Firet 1978:19; Long 2009b:18). Recently, the idea of a public practical theology has become increasingly relevant as research focus (Magezi 2018:3; Miller-McLemore 2012:6; Venter 2016:2). Within these conspicuous turns and shifts of approach, the pivotal role of the preacher within the triangular relationship between text, listener and preacher also emerged in leaps and bounds as an important topic (Dingemans 1991:14; Kruger \& Venter 2002:181; Troeger 2009:119).

Consequently, the highly dynamic model of meta-discourse adopted by Hyland (2005:22) focusses on decision-making in communication and highlights the system of making meanings. In charting the shape of new developments, another shift in research has emerged, namely the shift 
towards defining imagination, re-imagination and a focus on the stirring of memories (cf. Arthurs 2017:13; Brueggemann 2005:18; Troeger 2009:119). The place of the listener in the liturgical communication process is being scrutinised as an intriguing aspect with multifaceted angles. One aspect emerging from this focus is the difference between mere hearing and effective (mindful) listening (cf. Kruger 2017:14; Pakpahan 2012:118; Roskies 2015:221; Sabbagh 2016:12; Tyagi 2013:44). The aim of achieving full, conscious and active participation in worship has been a universal cry among scholars and leaders of worship (Burton-Edwards 2013:41). Continuous liturgical formation should involve liturgical activities, because by participating in liturgical activities the mind, emotions and body of members work together as a holistic entity, as the Body of Christ (cf. Smith 2009:40).

This is exactly where the present research intends to focus, namely the importance of listening within the immediate framework of participation in liturgy. The aim of this presentation is to indicate that viewing the act of listening as an integral liturgical activity has to reckon with hearing, understanding, remembering, evaluating and responding to messages (Tyagi 2013:2).

\section{Analysis of the concept of remembrance (recognition) within an inter-disciplinary framework}

\section{Analytical perspectives on recognition from the viewpoint of social psychology and communication sciences}

Cartledge (2003:15) and Pieterse (2001:13) indicate the importance of an inter- and intra-disciplinary approach to practical theological research, involving in this instance a communicative-hermeneutical approach. Such an approach enables researchers not to over-simplify their discourse.

Perspectives on remembrance (recognition) as a process of engramming from the viewpoint of social psychology: Remembrance in its functioning is not a cycle but rather an arrow aimed at significance. Remembrance renews and edits people's memories. Memories one should acknowledge, fade like ink ageing on a handwritten letter (Arthurs 2017:32). Therefore, neuroscientists often utilise the concept of engramming in order to describe the process of remembering. An engram is a pathway created in the brain when people receive information or enjoy new experiences. These pathways could be called memory traces (Arthurs 2017:32). Engramming harmonises new information with old information. Swartz et al. (2004:241) for this very reason connect the concept of recognition with remembrance. Atkins (2004:15) confirms this idea and makes the intriguing point that recognition as a process of remembrance occurs within the framework of the ability to remember things with which one is familiar. Eysenck and Keane (2010:261) moreover highlight the idea that recognition has to do with the functioning of memory, which includes both memories of the past and familiarity with things past.
Language and especially active listening are indispensable tools within the engramming process (Kruger 2017:14). After all, language enables people to recall facts and has a definite trigger effect in people's ability to remember. It can be compared with the lines of the barcode on products. Words evoke memories and have a trigger effect. In the same vein, schemes are mental structures of preconceived ideas which people employ to organise their knowledge (Arthurs 2017:32). People are more likely to notice things that fit into their schemata, and they actually tend to reinterpret it in order to make it fit into familiar frameworks. It is important to note that people are incapable of paying attention to all data they receive (Arthurs 2017:33). Schemes and previous experiences involving preachers and the act of preaching are therefore closely interwoven and will influence the kinds of things that will be remembered (Eysenck \& Keane 2010:401).

Schemes could therefore be regarded as previous learning experiences (Swartz, De La Rey \& Duncan 2004:241). People's recognition of preaching and of liturgy differs precisely because their learning experiences and their encounters differ (Freeman 2012:37). A local congregation or a faith community has various kinds of experiences related to the ministry of the Word, and every member of the community of believers, respectively, also has their own variety of experiences. Schemata function as index cards that enable people to react to information they receive. Maladjusted schemes could possibly affect the act of listening in a negative sense, but editing of memories is inevitable.

Perspectives on the interaction between remembrance and inner speech in promoting communication: Hustvedt (2011:211) indicates that people are able to create stories (narratives) out of the things they remember. This is simultaneously offering the idea of a tension-field because people's memories could differ. Hustvedt further emphasises remembrance as a pivotal stage in people's involvement in the realisation of inner speech. The little voice inside a person's head, or inner speech, is a common everyday experience. It plays a central role in human consciousness at the interplay of language and thought. Inner speech is central to various cognitive functions. Murphy (1989:15) underlines the sometimes unconscious operation of inner speech and indicates that when people listen to messages and the way liturgical acts are conducted, they do so through the filters of inner speech as a communicative medium. Consider also that inner speech provides people with the ability to identify their thoughts with language.

Also referred to as verbal thinking, inner speaking, covert self-talk, internal monologue and internal dialogue, inner speech clearly plays an important role in trying to make sense of our lives (Roskies 2015:222). The concept of inner speech could be regarded as influential among those participating in liturgy as well as those listening to sermons, for it is defined as the way in which people communicate interpersonally (Wood \& Wood 1999:200). Words, sermons or a particular passage from Scripture are excitable and often lead towards a 
memory of another preacher, another sermon or a previous experience. Memories evoked by listening could differ while participating in the act of listening. Listening within the context of a participatory understanding of liturgy has to do with the acknowledgement that what is being heard will have an influence on people's own inner speech, and therefore, remembrance plays a pivotal role.

Interdisciplinary perspectives from communication sciences on active listening and recognition as the spark in the listening process: Whatever is happening in people's lives at the time of listening, including the way in which they are speaking to themselves at that moment, will have an influence not only on what they remember but also on the way in which they are listening (Kruger 2018:22). Preachers often feel as if they could just as well have been speaking to a wall because what they were saying and what people heard were not the same (Grant \& Borcherds 2009:45). Grant and Borcherds (2009:3) point out that people do not listen with their ears only. They hear with their eyes (vivid remembrances) and with their sense of touch as they become aware of feelings and emotions that arise from the message. People furthermore listen with their minds and with their imagination. Ramey (2010:10) expands on this idea and highlights the deeper-seated challenges that listeners face. He describes people who have a listening burnout. Week after week, seemingly good communication is heard, but without penetrating hearers' minds or transforming people's lives. Ramey (2010:11) goes as far as to entertain the idea of a kind of expository listening as a process that discerns what to do with a sermon while listening to it.

Liturgists (also preachers) could possibly blame listeners for not really listening to what is being communicated but the process is far more complicated than this. Different elements determine the quality of what is heard. The listener's horizon of understanding and his or her unique kind of experience should be regarded as important during the preparation and the delivery of sermons. Remembrance should therefore be singled out as an important phase of igniting the participatory listening process to achieve the fusion of horizons. Disturbance during any phase could cause the process to be skewed. Remembering within the active listening process has to do with the process of storing the meaning of messages so that it could be recalled later on and be edited (Steinberg 2011:173).

Active listening is a process of making sense of oral input by carefully attending to the message itself. Tubbs and Moss (2008:246) express their opinion regarding the various ways in which people could listen to communication, namely false listening (people pretend to listen to messages), biased listening (people hear what they want to hear) and partial listening (people have good intentions to listen, but they become distracted). Active listening entails empowering listeners to recognise that they are familiar with the message and that they have had previous encounters of the same nature.
The stomach of memories - Augustine's view: Augustine elaborates on a particular aspect of the interpersonal participation of listeners by saying 'I came into the fields and spacious palaces of my memory, where are treasures of countless images of things of every manner' (Casey 1987:2). Against this background, he describes human memory as a stomach that holds both pleasant and less pleasant memories (Venter, Symington \& Van Wyk 2007:45). He suggests that human senses convey memorable things to the storehouse of memory (Casey 1987:11). His most striking metaphor for memory may be the 'stomach of the mind' (venter animi), where food is stored without tasting, but later brought forth for rumination. This metaphor strikes the ear as odd and even repulsive but the brilliance of the image resides in the notion that memories are held and digested, eventually to nourish the whole body.

In conjunction with Augustine's view, the phrase 'The Lord's remembrancers' was coined by Lancelot Andrewes, chaplain to Queen Elizabeth and King James I (Arthurs 2017:29; Casey 1987:12). Andrewes drew his metaphor from the royal court. The king's (or queen's) Remembrancer is the oldest judicial position in continual existence in Great Britain, having been created in 1154 by Henry II. Today, it amounts to a ceremonial position but for centuries the Remembrancer's job was to put the lord's treasurer and barons of court in remembrance of pending business, taxes paid and unpaid and other matters pertaining to the benefit of the crown. This historical situation reminds liturgists (preachers) of their responsibility to enable participants to see the old and the new of remembrances in order to enjoy new perspectives for the future. The storehouse of listeners' memories is invaluable. By enabling listeners to remember valuable aspects of God's treasury, treasures are offered, and, as explained earlier on, editing or engramming of memories eventually takes place.

\section{Normative perspectives on remembrance - $\alpha v \alpha \mu v \eta \sigma i \varsigma$}

Remembrance has to do with the understanding of reality of the past in such a way that the events of the past become a force in the present (Arthurs 2017:13). It is true in more than one sense that remembrance (recognition) equals intriguing participation in life, therefore igniting people's remembrances in preaching and in liturgy to reunite them mentally, emotionally and volitionally with the God who is proclaimed in the sermon.

\section{Old Testament perspectives on remembrance (recognition)}

The concept of remembering stands central to the Old Testament and as such extends itself to enable a specific function within the present (Loader 2012:583). For example, the verb for $z k r$ occurs 222 times in the Old Testament (Merrill 2000:28). Remembering enters the liturgical process, as indicated, for it is precisely the person and works of God that must be brought to mind as objects of adoration and wonder, 
and these are recovered only to the extent that the worshipper has the capacity to recall them (Vallet 2011:158). But, it is important to realise that it is characteristic of the Old Testament that every event and especially every feast were used as a teaching opportunity ${ }^{3}$ (Poorthuis 1989:25). The following two examples illustrate this idea. The importance of the Sabbath and the idea that Israel should observe (i.e. remember) the Sabbath day to keep it holy carry the idea of devotion (Le Roux 2006:1010). God recalls our sins, sees our transgressions, brings to light the misdeeds we try to hide (Cilliers 2019:95). Cilliers further indicates that God is not fooled by people's pretence. God indeed remembers. However, sin is not all that God remembers. God looks further back, beyond people's sinful past, to the compassionate history God created - especially remembering that. As in the case of Israel in Egypt, the place of slavery. Why were the Israelites there? There could be only one reasonable answer - through their own actions. Their disobedience and rebelliousness towards God landed them in this situation. But Israel's groans and cries for help also went up to God (Ex 2:23). God remembered their saddening transgressions, but also God heard their groaning and God remembered his covenant with Abraham, with Isaac and with Jacob (Ex 2:24,25). God thinks of this covenant (Cilliers 2019:95). God also recalls God's mercy. This godly self-remembrance is a key moment, which keeps on repeating throughout the Bible.

In time, Moses (according to the Old Testament) appointed men, priests, whose main task it was to see that the people never forgot what happened on the night they ate the Paschal lamb. The lamb kept alive Israel's faith in God. And the Lord told them that the firstborn of their sons should be given to him and that they should do the same with their sheep. The firstborn of the beasts were to be sacrificed and the firstborn sons were to be redeemed with a sacrificial lamb (Le Roux 2006:1012). The importance of carrying across remembrance from one generation to another should therefore be recognised. After all, children (and even adults) learn best by what they see and experience, for instance when something is demonstrated ritually or symbolically experienced, with the result that real learning takes place. In Hebrew culture, children occupy a special place in the learning process. Adults can learn much from the questions of children (Le Roux 2006:1026). Fundamental to Israel's faith was the recognition and recollection that Yahweh was Israel's God (Merrill 2000:6). In the Old Testament, people were encouraged not only to remember God's acts, but also to remember God himself (Pakpahan 2012:118). In view of God's relationship with Israel through his covenant and the relationship between the two covenant partners, listening to God and remembrance of him receive priority. Not only does Israel remember God, God himself actually remembers his relationship with his children.

3. On the doorposts of each house, it is still customary for the Jewish people to nail mezuza: this word, simply meaning 'doorpost', came to be applied to a small box made of wood or metal, in which a rectangular piece of parchment containing Deuteronomy 6:4-9 and 11:13-21 were set. The biblical basis for this practice is Deuteronomy 6:8: 'You shall write [the divine words] on the doorposts of your Deuteronomy 6:8: 'You shall write [the divine words] on the doorposts of your
houses and your gates'. They use every opportunity to teach the 'words of God' to houses and your
their children.
Baxter (2010:7) indicates that the Old Testament indicates various aspects of what should be remembered and that God himself makes it clear what he wants people to remember. $\mathrm{He}$ even instructs Israel to establish memorial stones, 12 of them, when they enter the Promised Land (Jos 4). Whenever they look at the Jordan River, they should remember the fact that it was God's gracious and almighty acts that enabled them to enter the land of Canaan. These memorial stones provided parents with a teaching tool: they were able to instruct the next generation in accordance with their memories. However, Baxter (2010:9) regards it as important to recognise that the memorial stones were important so that all people could understand that the hand of God is mighty (Jos 4:24).

At the very least, this remembering within the covenant seems to imply that the God who performed past mighty deeds is the same God who is present with his people as they remember those deeds. He is present as the living God, bound to them in election and covenant, as he was to their ancestors in days past, for he is Yahweh, 'I am who I am'. In fact, the act of remembrance is based on the assurance that God himself is a remembering God. Remembrance (recognition) of past events and of God's acts in the past creates new memories and turns encounters with him into meaningful events. People in the Old Testament are therefore also exhorted to remember God at various feasts such as Passover, the Feast of the Tabernacles and the Purim Feast (Vorster 2011:57). At these feasts, people remembered God's acts of deliverance (cf. the exodus motive) and his providence. However, it is important to realise that the source for remembrance is always God's activity. The past subsequently becomes present in cultic rituals, and therefore, believers become participants in God's mighty deeds of salvation in the past (Jones 1986:437). Again, the recognition and recollection that Yahweh was Israel's God was fundamental to Israel's faith (Vallet 2011:32). An encounter with the person of God as a way of remembering him is therefore not complete without an understanding of and response to his mighty works (Baxter 2010:10).

\section{New Testament perspectives on remembrance (anamnesis)}

From the perspective of the New Testament, remembrance (recognition) is closely related to the idea of significance or the meaning of events and words (Pakpahan 2012:139). The idea of God as God that remembers is taken to fulfilment in and through Jesus Christ's suffering and victorious resurrection. Through the act of remembrance, the person or deeds that are remembered are brought to the realm of the here and now within the framework of celebration (Brouwer 2009:25). For meaning-seekers, meaning is created in this process. From a New Testament perspective, furthermore, the idea of re-lived and re-experienced experiences is vivid within a new and meaningful realm. Pakpahan (2012:115) explains that, within the New Testament, the concept of remembrance (anamnesis) is often utilised within the context of an encounter with God (liturgy). Through remembrance, the active God of the past is remembered as active in the 
present. This very idea provides dynamic hope for the future. It moves like a wheel that is able to move backwards and also forwards. A much-cited Dutch scholar, Immink (2014:53-55), hits the nail on the head when he avers that Christ is expected in the worship service, while he is not simply there at people's command. Liturgists are servants and not magicians. Therefore, the idea of epiclesis, the invocation of the Holy Spirit, is important. It is the Holy Spirit who opens people's minds and provides receptivity in people's hearts (De Klerk 1987:40-42).

In the letter to the Hebrews, also regarded as a threedimensional sermon, believers are reminded to honour their responsibilities of faith (Kruger \& Venter 2006:54). In the book (sermon) of Hebrews, people are addressed in the context of a praxis of decay. The letter is written or preached to people who became disheartened in the face of their concrete circumstances. Uncertainty about understanding difficult circumstances prompted them to question whether it was still worth being Christian in their contemporary world (Kistemaker 1984:5). Bruce (1990:5) emphasises that to achieve this, a distinct line of argumentation has to be adhered to, namely reconsidering the value of Jesus Christ's message in their lives (cf. Heb 3:1 and 12:2-3).

Consider that the sermon to the Hebrews structures its contents in a unique manner (cf. Hume 1997:9-13). The idea of persuasion through preaching comes to the fore, especially when one considers the fact that it mentions the theme of attitude seven times, each time within its admonishing (paranetic) sections , as found in Hebrews 3:6, 4:11, 4:16, 6:11, 10:19, 10:35 and 13:6. Challenges are prominent within this book to the Hebrews when it comes to persuading believers who have lost energy and the sense of the meaningfulness of duties or actions such as encouraging each other, communion with each other and meeting each other. The listeners in this congregation longed for the good old days. The writer of this sermon does not, however, communicate with emphasis on the good old days. On the contrary, he underlines what it takes to live in the last days and the importance of here and now (Kruger \& Venter 2006:65).

The book contrasts two dispensations, namely the past and the present (Heb 1:1-3). God has communicated polumeros kai polutropos through fathers and prophets in the past, but in the last days he spoke through his Son. The purposefulness of God's communication is striking. He did not say all things at once but said it purposefully over the years. This involves an important lesson for preachers and liturgists, namely to plan carefully. As part of his manner of introducing an important focal point gradually and in a structured way, the preacher in the Hebrews sermon utilises Old Testament quotations on at least 35 occasions (cf. Ellingworth 1993:37). Ellingworth therefore utilises vivid memories of the past to provide dynamic perspectives for the present. For instance, Cromhout (2012) enumerates various figures from the Israelite tradition to encourage first listeners or readers to remain loyal themselves (Cromhout 2012:1). In Hebrews 2:1 it is emphasised that listeners should take heed of things that they have heard because of the fact that it is linked to salvation in Christ.

Hebrews 3 underlines the importance of regarding today as an important day. Striking here is the reference to Psalm 95:7-11, which highlights the lesson from history that one ignores God's communication at one's peril. The message is clear, namely that God's communication has to do with the fact that he himself is speaking. Listening to God's voice today means to listen decisively. Hebrews 10:3 builds on this

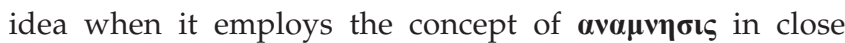
connection with Old Testament sacrifices. According to Bruce (1990:237), sacrifices brought by the high priest were remembrances of human sin. Flanigan (1997:197) concurs and indicates that the yomkippur (the annual day of atonement) underlines the idea that a vivid remembrance of what was reality and what is reality should provide direction for the future. People have been remembered of their sins and reconciliation in Christ. Long (1997:102) explains the stark contrast between something that should have happened regularly in the past and the message that Christ did something of significance, once and for all. Calvin (1994:133) therefore rightly connects the idea of Christ's reconciliation with daily and frequent remembrance. The interrelationship between knowledge of sin and reconciliation should be remembered frequently and on daily basis (DuToit 2002:161).

\section{Strategising perspectives on remembrance within the disciplines of homiletics and liturgics}

To guide participants within the liturgy of a worship service entails reminding listeners week after week of God's promises even when they are prone to forgetting (Arthurs 2017:25). Preaching what listeners have heard since they were children is in fact no homiletical nightmare but a reminding of the great truths of faith. This could be described as the stirring of memory that is able to prompt thankfulness, raising hope against any hope, fostering humility, encouraging obedience and prompting mercy in a merciless world (Arthurs 2017:8). More research on this topic is needed.

\section{Listening and the memoria Christi}

This article contends that a static understanding of the essence of a worship service cannot be maintained. The dialogical character and the various communicative acts within liturgy instead indicate dynamic liturgical understanding centred on listening-seeing-participating-and-continuation. The dynamic flow of listening to liturgical communication of distinct elements entails that participants have to realise that even their listening has relevance to seeing and acting differently. This is exactly where the optical lens of remembrance offers to be a helpful mechanism for a participatory involvement in liturgy. Van der Laan (1995:21) 
concurs and indicates the cognisance of memoria Christ $i$ in this process. The vivid remembrance of what God has done in and through his Son is central to liturgy (Vos \& Pieterse 1997:102). Listening in a worship service is influential not only for a participatory understanding of liturgy, but also for one's own perspective (seeing) of being transformed by liturgy. Participants are taking part in the act of listening and also in remembering memories about Christ. ${ }^{4}$

\section{Reminding (that is, stirring memory) as agent for the significance of daily life}

Remembrance as reminding, the stirring of memory and as the editing of memories needs to be scrutinised increasingly within research. Gaarden (2014b:28) indicates that remembrance is not merely about a mental understanding of words but about a new understanding (meaningidentification) where listeners' own stories could enter into dialogue with what is being communicated. The liturgist (preacher), who must uphold an attitude of being a listener among listeners, should first of all wade into the waters of remembering (Arthurs 2017:116). Each word and section of his or her formulation of the message has to be carefully scrutinised to enrich people's memories (Arthurs 2017:126).

Remembrance enables listeners to connect things that have been dismembered and amputated. In fact, the challenge is to remind people about things they actually know in order to promote connectivity with the message. The unique message of each liturgical element should prompt listeners to see what they may have been forgotten. A memorable participation within a given liturgy offers a permeating opportunity to scrutinise the fractured reality of life by remembering God's concern for human beings and the brokenness of life. The realisation of this remembrance should be applied to people's lives. Listening in liturgy as such invites people to look and see that new perspectives on daily life are indeed necessary. The beauty of this resides in offering new perspectives on reality as well as stirring memory, and not simply repeating threadbare platitudes (Arthurs 2017:7).

Liturgists are aware of the fact that the words utilised will connect with previous experiences (schemata) in listeners' lives. Listeners often refer to this connection when they talk about sermons afterwards. Moreover, they are not always able to remember the exact formulation or the words the preacher used in the sermon, but they are able to link the sermon with a concrete situation in their lives (De Leede \& Stark 2017:141). Troeger's (2009:62) view that engagement with life occurs at the level of the imagination therefore calls on liturgical reflection, especially in respect of liturgical language that offers hope to people. Imagination may be defined as the ability to hold before the mind's eye a surprising image of something that is present but also not present. An associative interaction takes place when listening results in remembrance of a new set of questions and challenges within the listeners' minds (previously explained 4. Bohren (1974:159) refers to this idea as 'Die Geistesgegenwart umfasst die Zeiten'. as inner speech). This new understanding does not necessarily always stem from the exact intent of the liturgist, which is why what is remembered could differ from what has been communicated.

An additional important aspect of the kind of involvement that remembrance offers to listeners could be called critical interaction with the content. This critical interaction would occur, for instance, when a preacher's understanding and exposition of a text are not consistent with the listener's interpretation (Gaarden 2014b:22). This clash between what is preached and what is true according to people's inner speech could nonetheless pave the way for a new kind of understanding to arise. Gaarden (2014b:25) proceeds and indicates that there is a further kind of participation in the listening process, namely a kind that is beyond human words. This could be called contemplative participation, where listeners know they have listened, but afterwards cannot recall the relevant information. Listeners are convinced of the fact that the liturgy means a lot to them, but they cannot retrieve that information. Listeners are nonetheless adamant about what the worship service has meant. They feel relaxed and silenced in their state of being. It is clear that participation is more mysterious than what the naked eye believes. A lens of remembrance indeed provides dynamic possibilities.

\section{Conclusion}

In this article the author investigated the prospect that remembrance as an optical lens of the mind that edits memories through participatory listening in liturgy, offering new perspectives for the disciplines of liturgics and homiletics. A qualitative literature study has demonstrated that, within this context, an ontological shift is inevitable. A shift from a passive listening approach to one of acting, entails a participatory approach where listening occurs in which memories are edited at the hand of vivid remembrances. This approach could enrich liturgical and homiletic praxis by stressing the awareness that remembrances are avenues through which listeners become participants. It is clear that the relationship between liturgical language and the activity of listening should be addressed carefully, as only a single word is able to retrieve an image.

\section{Acknowledgements Competing interests}

The author declare that no competing interest exist.

\section{Author contributions}

F.P.K. is the sole author of this article.

\section{Ethical considerations}

This article followed all ethical standards for research without direct contact with human or animal subjects. 


\section{Funding information}

This research received no specific grant from any funding agency in the public, commercial, or not-for-profit sectors.

\section{Data availability statement}

Data sharing is not applicable to this article as no new data were created or analysed in this study.

\section{Disclaimer}

The views and opinions expressed in this article are those of the authors and do not necessarily reflect the official policy or position of any affiliated agency of the authors.

\section{References}

Allen, W.O., 2010, The renewed homiletic, Fortress Augsburg, Minneapolis, MA. Arthurs, J.D., 2017, Preaching as remembering, Intervarsity Press, Westmont, IL. Atkins, P., 2004, Memory and liturgy: The place of memory in the composition and practice of liturgy, Ashgate, London.

Baxter, T.E., 2010, 'What do these stones mean?', Four Lakes Church of Christ 7(1), $1-12$.

Beale, G.K., 2008, We become what we worship: A biblical theology of idolatry, IVP Academic, Nottingham.

Bohannon, J.S., 2006, 'Preaching and the emerging church', Faith \& Mission 23(2), 55-77.

Bohren, R., 1974, Die Geistesgegenwart umfasst die Zeiten, kaiser, Gütersloh verlaghaus, Nördlingen.

Bonhoeffer, D., 1959, Creation and fall, SCM Press, London.

Bothma, Y., Greeff, M., Mulaudzi, F.M. \& Wright, S.C.D. (eds.), 2010, Research in Health Sciences, pp. 10-222, Pearson, Cape Town.

Brienen, T., 1987, De liturgie bij Johannes Calvijn: Zijn publicaties en zijn visies, De Groot Goudriaan, Kampen.

Brouwer, R., 2009, 'Preken in context over de homiletische situatie', in M. Barnard F. Borger, K. Bregman, R. Brouwer, G. van Ek \& G. Immink (reds.), Als een leerling leren preken, pp. 21-35, Boekencentrum, Zoetermeer.

Bruce, F.F., 1990, The Epistle to the Hebrews (The New International Commentary on the New Testament), Eerdmans, Grand Rapids, MI.

Brueggemann, W., 1978, The prophetic imagination, Fortress, Philadelphia, PA

Brueggemann, W., 2005, Reality, grief, hope: Three urgent prophetic tasks, Eerdmans, Grand Rapids, MI.

Burton-Edwards, T.W., 2013, 'Perspectives and limitations of current theories in neuroscience and cosmology in describing "full, conscious and actual participation in liturgical celebrations"', Liturgy 28(4), 41-59. https://doi.org/10.1080/045806 $3 X .2013 .803852$

Buttrick, D., 1987, Homiletic: Moves and structures, Fortress, Philadelphia, PA.

Calvin, J., 1994, The epistle to the Hebrews, in Calvin's commentaries, pp. 1-213, Eerdmans, Grand Rapids, MI.

Cartledge, M.J., 2003, Practical theology - Charismatic and empirical perspectives, Paternoster, London.

Casey, E.S., 1987, Remembering: A phenomenological study, Indiana University Press, Bloomington, IN.

Cilliers, J.H., 2000, Die genade van gehoorsaamheid, Lux Verby, Wellington.

Cilliers, J.H., 2001, 'As it is in heaven? Reflections on liturgical reframing', Scriptura $1002,511-519$

Cilliers, J.H., 2012, The optics of homiletics: Preaching as reframing of perspective, Rsamprinters, Stellenbosch.

Cilliers, J.H., 2019, Timing grace: Reflections on the temporality of preaching, Sun Media, Stellenbosch.

Craddock, F.B. (ed.), 1985, Preaching, Abingdon press, Nashville.

Cromhout, M., 2012, 'The "cloud of witnesses" as part of the public court of reputation in Hebrews', HTS Teologiese Studies/Theological Studies 68(1), a1151. https://doi. org/10.4102/hts.v68i1.115

De Klerk, B.J., 1987, Die Heilige Gees en die erediens, TSP Publikasies, Potchefstroom.

De Klerk, B.J. \& Kruger, F.P., 2017, 'Continuous formation of liturgy through social cognition', HTS Teologiese Studies/Theological Studies 72(1), a3170. http://dx.doi. org/10.4102/hts.v72i1.3170

De Leede, B. \& Stark, C., 2017, Ontvouwen: Protestantse prediking in de praktijk Boekencentrum, Soetermeer.
Dewhurst, S.A. \& Perry, L.A., 2000, 'Emotionality, distinctiveness and recollective experience', European Journal of Cognitive Psychology 12, 541-551. https://doi. org/10.1080/09541440075005022

De Wet, F.W. \& Kruger, F.P., 2013, 'Blessed are those that hunger and thirst for righteousness - Shaping the ethical dimension of prophetic preaching in a context of corruption, Verbum et Ecclesia 43(1), 0722. https//doi.org/10.4102/ ( ve.v34i1.722

Dingemans, G.D.J., 1991, Als hoorder onder de hoorders, Kok, Kampen.

Dingemans, G.D.J., 1996a, Practical Theology in the academy: A contemporary overview, Kok, Kampen

Dingemans, G.D.J., 1996b, Manieren van doen: Inleiding tot de studie van de Praktische Theologie, Kok, Kampen, p. 32-35.

Du Toit, A. (ed.), 2002, Romeine: Hartklop van die evangelie: Beleef God se genade, CTP Drukker, Parrow.

Ellingworth, P., 1993, The Epistle to the Hebrews (The New International Greek Testament Commentary), pp.1-414, Eerdmans, Grand Rapids, MI.

England, F., 2017, 'Music, theology, and space: Listening as a way of seeking God', Acto Theologica 37(1), 18-40. https://doi.org/10.4314/actat.v37i1.3

Eysenck, M.W. \& Keane, M.T., 2010, Cognitive psychology, Psychology Press, New York, NY.

Firet, J., 1978, Het agogisch moment in het pastoraal optreden, Kok, Kampen.

Flanigan, J.M., 1997, 'Hebrews-What the Bible teaches', in Ritchie New Testament commentaries, pp. 1-121, John Ritchie, Kilmarnock.

Freeman, S.R., 2012, Preaching and peace-making: A Mennonite homiletic of justice, peace and reconciliation, Saint Michael's College, Toronto.

Gaarden, M., 2014a, 'The emerging sermon. The encounter between the words of the preacher and the listeners' experience', paper presented at Aarhuis University, Danish Church Education for Pastoral Studies, Denmark.

Gaarden, M.L., 2014b, Listeners as authors in preaching, Aarhus University Press, Copenhagen.

Grant, T. \& Borcherds, R., 2009, Communicating at work, Van Schaik, Pretoria.

Green, C., 1989, Imaging God, Harper \& Row, San Francisco, CA.

Hauerwas, S., 1989, Resident aliens, Abingdon, Nashville, TN.

Hauerwas, S., 2002, The Hauerwas reader, Duke University Press, London.

Hervieu-Léger, D., 2000, Religion as a chain of memory, Rutgers University Press, New Brunswick, NJ.

Hume, C.R., 1997, Reading through Hebrews, SCM Press, London.

Hustvedt, S., 2011, Three emotional stories: Reflections on memory, the imagination, narrative, and the self', Neuropsychoanalysis 13(2), 187-298. https://doi.org/10. 1080/15294145.2011.10773674

Hyland, K., 2005, Meta-discourse: Exploring interaction in writing, Continuum, New York, NY.

Immink, F.G., 2014, The touch of the sacred: The practice, theology and tradition of Christian worship, Eerdmans, Grand Rapids, MI.

Jones, R.C., 1986, 'The Lord's supper and the concept of anamnesis', Word \& World 6(4), 434-444

Kensinger, E.A., 2009, 'Remembering the details: Effects of emotion', Emotion Review 1(2), 99-113. https://doi.org/10.1177/1754073908100432

Kimball, D., 2004, Emerging worship: Creating worship gatherings for new generations, Zondervan, Grand Rapids, MI.

Kistemaker, S.J., 1984, Hebrews, in Exposition of the Epistle to the Hebrews (New Testament Commentary)? Baker, Grand Rapids, MI.

Koester, C.R., 2005, 'Conversion, persecution, and malaise: Life in the community for which Hebrews was written', HTS Teologiese Studies/Theological Studies 61(1/2) 231-251. https://doi.org/10.4102/hts.v61i1/2.444

Kruger, F.P., 2017, 'Rekognisie as meganisme vir die identifisering van die betekenis van liturgiese elemente in die erediens', Verbum et Ecclesia 38, a1694. https://doi. org/10.4102/ve.V38i1.1694

Kruger, F.P., 2018, Recognition as the spark in the exchange of ownership of a sermon: $A$ homiletic lens on the influence of recognition on active listening, Ecclesiology 15(2), 1-20. https://doi.org/10.1163/17455316-20180003

Kruger, F.P. \& Venter, C.J.H., 2002, 'Prediking en die gesindheid van hoorders: Basisteoretiese perspektiewe vanuit Hebreërs', In die Skriflig 36(4), 573-592. https://doi.org/10.4102/ids.v36i4.526

Kruger, F.P. \& Venter, C.J.H., 2006, 'Die prediking van geloofsverantwoordelikheid: Homiletiese perspektiewe vanuit Hebreërs', Praktiese Teologie in Suid-Afriko 21(1), 55.

Kubicki, J.M. (ed.), 2006, The presence of Christ in the gathered assembly, Continuum, London.

Lange, E., 1987, Predigt als Beruf: Aufsätze zu Homiletik, Liturgie und Pfarramt, Christian Kaiser, München.

Le Roux, M., 2006, 'Celebrating the feasts of the Old Testament in Christian contexts', HTS Teologiese Studies/Theological Studies 62(3), 1001-1010.

Loader, J.A., 2012, 'Prosthetic Memory in the Old Testament', Old Testament Essays, 25(3): 583-597.

Long, T.G., 1997, Preaching from memory to hope, Westminster John Knox, Louisville, KY. 
Long, T.G., 2009a, Preaching from memory to hope, Westminster John Knox, Louisville, $\mathrm{KY}$.

Long, T.G., 2009b, The witness of preaching, Westminster John Knox, Louisville, KY.

Louw, D.J., 2011, 'Ta splanchna: A theopaschitic approach to a hermeneutics of God's praxis: From zombie categories to passion categories in theory formation for practical theology of the intestines', HTS Teologiese Studies/Theological Studies 67(3), a1087. https://doi.org/10.4102/hts.v67i3.1087

Magezi, V., 2018, 'Public pastoral care as nexus and opportunity for a transformed practical theology within decolonisation discourse in South African highe education', In die Skriflig 52(1), a2327. https://doi.org/10.4102/ids.v52i1.2327

Malström, H., 2016, 'Engaging the congregation: The place of meta-discourse in contemporary preaching', Applied Linguistics 37(4), 561-582. https://doi org/10.1093/applin/amu052

McClure, J.S., 1995, The roundtable pulpit: Where leadership and preaching meet, Abingdon, Nashville, TN.

McLaren, B.D., 2008, Church emerging: Or why I still use the word postmodern but with mixed feelings, Baker, Grand Rapids, MI.

Merrill, E.H., 2000, 'Remembering: A central theme in biblical worship', Journal of the Evangelical Theological Society 43(1), 27-36.

Miller-McLemore, B.J., 2012, 'Five misunderstandings about practical theology', International Journal of Practical Theology 16(1), 5-26. https://doi.org/10.1515/ ijpt-2012-000

Moltmann, J., 2008, A broad place: An autobiography, Fortress, Minneapolis, MN.

Müller, B.J., 1996, 'Profetiese prediking op weg na 2000 plus', in M. Nel (red.), Prediking en kommunikasie in konteks, pp. 1-111, Makro Boeke, Pretoria.

Murphy, J.M., 1989, 'Listening in a second language: Hermeneutics and inner speech', TESL Canada Journal 6(2), 23-38. https://doi.org/10.18806/tesl.v6i2.550

Ochsner, K.N., 2000, 'Are affective events richly "remembered" or simply familiar? The experience and process of recognizing feelings past', Journal of Experimental Psychology: General 129, 242-261.

Ott, C. \& Strauss, S.J., 2010, Encountering theology of mission, Baker, Grand Rapids, MI.

Pakpahan, B.J., 2012, God remembers: Towards a theology of remembrance as a basis of reconciliation in communal conflict, VU University Press, Amsterdam.

Pieterse, H.J.C., 2001, Prediking in 'n konteks van armoede, Unisa, Pretoria.

Pleizier, T., 2013, Religious involvement in hearing sermons: A grounded theory study in empirical theology and homiletics, Eburon, Delft.

Poorthuis, M., 1989, Hamer op de rots, Folkertsma Stichting voor Talmudica, Hilversum.

Ramey, K., 2010, Expository listening, Kress Biblical Resources, Michigan.

Ricoeur, P., 2004, Memory, history, forgetting, transl. K. Blamey \& D. Pellauer University of Chicago Press, Chicago, IL. https://doi.org/10.7208/chicago/ 9780226713465.001.0001

Roskies, A., 2015, Thought, language and inner speech, Dartmouth College Press, Lebanon, $\mathrm{NH}$.

Sabbagh, T.M., 2016, Listening: The lost communication skill, Florida Atlantic University, Boca Raton, FL.

Saliers, D.E., 1994, Worship as theology: Foretaste of glory divine, Abingdon, Nashville, TN.

Saliers, D.E., 2010, The body remembers long after the mind, Columbia Theological Seminary, Decatur, GA.
Sapiro, G., 2016, 'Faulkner in France: Or how to introduce a peripheral unknown author in the center of the world republic of letters', Journal of World Literature 1(3), 391-411. https://doi.org/10.1163/24056480-00103007

Smit, D.J., 2008, Geloof en openbare lewe, Sun Press, Stellenbosch.

Smith, J.K.A., 2009, Desiring the kingdom: Worship, worldview and cultural formation, Baker Academic, Grand Rapids, MI.

Smith, J.K.A., 2013, Liturgy as a way of life: Embodying the arts in Christian worship, Baker Academic, Grand Rapids, MI.

Steinberg, S., 2011, An introduction to communication studies, Juta, Cape Town.

Schwartz, L., De la Rey, C. \& Duncan, N. (eds.), 2004, Psychology: An introduction, Oxford University Press, Oxford.

Schlinger, M.A., 2014, 'Transformative learning, educational vision for the 21st century', Convergence, 33:158-161.

Troeger, T.H., 2009, 'Seeing visions and dreaming dreams: The imaginative power of preaching hope', in C. Vos, L.L. Hogan \& J.H. Cilliers (eds.), Preaching as a language of hope, pp. 73-80, Boekencentrum, Zoetermeer.

Tubbs, S. \& Moss, S., 2008, Human communication: Principles and contexts, McGrawHill, New York, NY.

Tubbs-Tisdale, L., 2010, Prophetic preaching: A pastoral approach, Westminster John Knox, Louisville, KY.

Tyagi, B., 2013, Listening: An important skill and its various aspects, Longman, London.

Urbaniak, J., 2015, 'Religion as memory: How has the continuity of tradition produced collective meanings? - Part one', HTS Teologiese Studies/Theological Studies 71(3), a2815. https://doi.org/10.4102/hts.v71i3.2815

Van der Laan, J.H., 1995, 'Leesroosters voor de zondagse viering. Een informatief overzicht', Practishe Theologie, 22(4):4-29.

Vallet, R.E., 2011, The steward living in covenant: A new perspective on Old Testament stories, Scriptura 76(2), 157-159.

Venter, P., Symington, J. \& Van Wyk, A., 2007, Augustinus se belydenisse, Lux Verbi, Wellington.

Venter, R., 2016, 'Theology and the (post-) apartheid university: Mapping discourses, interrogating transformation', Transformation in Higher Education 1(1), a5. https://doi.org/10.4102/the.v1i1.5

Viola, F., 2008, Pagan Christianity? Exploring the roots of our church practices, Tyndale House, Oxford.

Vorster, J.M., 2011, Menswaardigheid, versoening en vergiffenis, Potchefstroomse Teologiese Publikasies, Potchefstroom.

Vos, C.J.A. \& Pieterse, H.J.C., 1997, Hoe lieflik is u woning, RGN, Pretoria.

Vosloo, R., 2015, 'Commemoration, rememoration and reformation: Some historicalhermeneutical celebrations of the Dutch Reformed Church', Studia Historiae Ecclesiasticae 41(3), 79-91. https://.doi.org/10.17159/2412-4265/2015/764

Welker, M., 2000, What happens in communion? Baker Academic, Grand Rapids, MI.

Wepener, C., 2017, Die reis gaan inwaarts, Sun Media, Stellenbosch.

Witvliet, J.D., 2003, Worship seeking understanding: Windows into Christian practice, Baker Academic, Grand Rapids, MI.

Wolterstorff, N., 1992, 'The reformed liturgy', in D.J. McKim (ed.), Major themes in the Reformed tradition, pp. 273-303, Eerdmans, Grand Rapids, MI.

Wood, S.E. \& Wood, E.G., 1999, The world of psychology, Allyn \& Bacon, Boston, MA 